\title{
The Practice and Future of Financing Science, Technology, and Innovation
}

\author{
Ricardo Seidl da Fonseca \\ Visiting Scholar, and former Chief Officer at the United Nations Industrial Development Organization (UNIDO), \\ r.seidl.fonseca@gmail.com \\ Institute for International Science and Technology Policy, George Washington University's Elliott School of International \\ Affairs, 11957 E St NW, Suite 403 Washington, D.C. 20052, United States \\ Alex Pinheiro Veloso \\ Chief Financial Officer, veloso7@yahoo.com \\ Gestora de Inteligência de Credito, Alameda Araguaia, 2104 - Alphaville Industrial, Barueri — SP, 06455-000, Brazil
}

\begin{abstract}
$\mathrm{T}$ he importance of financing science, technology and innovation (STI) is growing increasingly relevant and is changing its content. New, more comprehensive financing mechanisms are emerging. With STI costs rising and government budgets shrinking, research and innovation has become more cooperative and network-based.

The paper discusses the different instruments and incentives available for governments to improve the financing of innovation. Two case studies illustrate government efforts

from the United Kingdom and Brazil towards innovation financing issues. Lastly, recent and future STI financing trends are reviewed.

Governments continue to play a crucial and determining role in STI financing, whether through financial incentives, fiscal incentives or a mix of both. Countries with low national innovation performance should assign more weight to fiscal incentives, while countries with high innovation performance financial incentives prove more efficient.
\end{abstract}

Keywords: science, technology and innovation (STI); funding; public-private partnerships; financial incentives; fiscal incentives; project financing.
Citation: Seidl da Fonseca R., Pinheiro-Veloso A. (2018) The Practice and Future of Financing Science, Technology, and Innovation. Foresight and STI Governance, vol. 12, no 2, pp. 6-22. DOI: 10.17323/2500-2597.2018.2.6.22 
$\mathrm{F}$ inancing science, technology, and innovation ("STI") has grown in importance and complexity over recent decades. The move towards a national innovation system approach, as opposed to linearmodel-based efforts, has become prevalent in the STI field [OECD, 1997a, 1999]. Concurrently, an increasing number of mechanisms have been made available in order to channel resources toward STI activities. Governments continue to play a critical and determining role in STI financing. However, with STI costs on the rise and increasing government budget restrictions, simple government grants and subsidies have begun giving way to the use of more complex instruments. Governments may now also engage in investment arrangements with the private sector, recognizing "the fact that research and innovation are increasingly cooperative and network-based" [OECD, 2014]. Public-private partnerships ("PPP") are ever more popular in STI, with PPP projects generally being financed via Project Finance arrangements [Hodge, Greve, 2007].

In such context, a complete understanding of a country's national innovation system is crucial for identifying leverage points for enhancing innovative performance and overall competitiveness. After a brief discussion of the concept, origin, and development of STI financing, this paper focuses on the different instruments and incentives governments may use to improve the financing of innovation. Two case studies are then explored, illustrating government efforts from the United Kingdom and Brazil towards innovation financing issues. Lastly, the paper reviews recent and future STI financing trends.

\section{The Development of Approaches to STI Financing}

Early innovation models were developed around the concept that innovation occurred in a linear fashion, with basic research as the primary initiator of innovation, following through design, engineering, and manufacturing, to marketing and sales [Rothwell, 1994]. Therefore, increasing scientific inputs into the pipeline would lead to a direct increase in the number of new innovations and technologies [OECD, 1997a]. As a result, STI funding generally also followed simplistic, linear-fashion methods. Initial phases of the innovation process (basic research) were heavily dependent upon public sector funding, while the diffusion process (marketing and sales) relied nearly exclusively on the private sector, with intermediary processes (applied research and development and manufacturing) being funded by both the public and private sectors.

With the rise of and shift to systemic approaches to the study of technological development, the innovation process is no longer seen as a sequential pattern, with the preceding phase having to be cleared before moving to the next. Innovation can come from different sources and at any stage of innovation process and may also include product adaptations and incremental improvements to processes. Hence, innovation is a function of complex interactions among several stakeholders, with feedback loops occurring throughout. These stakeholders include cooperating and competing firms, public and private research institutes, universities and transfer institutions, interacting regionally, nationally, or internationally. As a nation's economy becomes more knowledge-intensive, an increasing number of players - in the private sector, public sector, and academia - are involved in the production and diffusion of innovation, and the effectiveness in gathering and utilizing knowledge from these institutions becomes an essential determinant of a country's competitiveness [OECD, 1997a]. Consequently, STI financing also grew in complexity and scope, incorporating new concepts to leverage innovative performance, recognizing regional, national, and international interactivity and cooperation among actors, as well as the economic importance of knowledge and knowledge flows. Such mechanisms include:

- formal measures such as tax policies and government subsidies;

- long-term funding commitments by government and industry organizations;

- government budget allocation to universities, research institutes, libraries, and other organizations involved in learning and innovation;

- funding programs managed by international and regional organizations;

- target funding managed by specialized institutions, such as Science and Technology Councils and Foundations;

- single-project funding via Project Finance.

Governments play, and will continue to play, a crucial and determining role in STI financing. Simple grants and subsidies are giving way to more complex instruments. With STI infrastructure and operating costs on the rise, governments have begun to engage in investment arrangements with the private sector. Public-private partnerships ("PPP") have become increasingly common across the globe [Hodge, Greve, 2007], with PPP projects generally being financed using Project Finance arrangements [EIB, n.d.].

The following sections discuss the basic fiscal and financial incentives available to governments, assess their advantages and disadvantages, as well as Project Finance tools.

\section{Government STI Financing}

Government policies involving regulations, taxes, financing, competition, and intellectual property can largely influence interactions and knowledge flows in innovation systems [OECD, 1997a]. Governments 
Table 1. Basic Government STI Financing Instruments

\begin{tabular}{|l|l|}
\hline \multicolumn{1}{|c|}{ Financial (non-fiscal) Incentives } & \multicolumn{1}{c|}{ Fiscal Incentives } \\
\hline - Grants, loans, subsidies & - Tax allowances \\
- Venture Capital Programmes & : Tax credits \\
- Equity Investment Guarantees & - Special depreciation rules \\
\hline Source: [European Commission, 2001]. & \\
\hline
\end{tabular}

can support innovation through financial incentives, fiscal incentives, or a mix of both. Financial incentives include grants, subsidies, low-interest loans, guarantee schemes, and venture capital programs. Fiscal incentives reduce the cost of a business to develop innovation activities and include tax allowances, tax credits, accelerated depreciation of assets, total or partial exemptions of capital gains, and favorable treatment for dividends [European Commission, 2001]. Table 1 summarizes the basic government STI financing instruments.

\section{Financial Incentives \\ Government Loans}

Governments may provide funding to venture capital or small firms via low-interest, long-term and nonrefundable loans. Low-interest loans provide below-market, subsidized interest rates to the borrower. Long term, or extended duration loans are aimed at relieving the capital constraints of early stage companies. Non-refundable loans are offered for strategic R\&D projects or in the case of borrower failure. Government loans may exert pressure on national budgets as exposure to default is both cyclical and unpredictable.

\section{Venture Capital Programs}

Government venture capital programs may be designed to help companies at various stages of development, either to finance the launch, early development, expansion, or even restructuring of a business. However, studies support the premise that start-up firms should benefit the most from such programs, as private funding to these firms is inadequate in most countries [OECD, 1997b].

Venture capital is usually riskier and less liquid than most other forms of financing. Governments can leverage the development of the venture capital industry directly by creating state-sponsored venture capital funds or establishing public incubators, or indirectly, by improving the venture capital industry infrastructure [OECD, 1996]. Table 2 summarizes measures that have been implemented at the European and national levels [Christofidis, Debande, 2001]:

\section{Guarantee Mechanisms}

A guarantee can be defined as "the assumption of responsibility for the payment of a debt or performance of some obligation if the liable party fails to perform to expectations". " Guarantee instruments include equity investment guarantees, export credit guarantees, political risk insurance, and credit guarantees. Equity investment guarantees and credit guarantees, in particular, are of greater importance for startup and technology-based firms and are discussed in further detail below. Equity guarantee programs are aimed at reducing investors' aversion to high-risk investments [OECD, 1997b]. Such programs are important to smaller venture capital funds, where the write-off of a significant portion of the portfolio may "reduce the level of residual operating funds to below a viable limit" [Murray, Marriott, 1998]. Equity guarantee programs "can be implemented as an instituted publicly supported insurance scheme or as a measure for the State to share in the cost of investment", covering up to $75 \%$ of an investment, with

\section{Table 2. Policy Measures to Support the Venture Capital Market}

\begin{tabular}{|l|l|l|}
\hline & \multicolumn{1}{|c|}{ Demand-side Measures } & \multicolumn{1}{c|}{ Supply-side Measures } \\
\hline $\begin{array}{l}\text { Direct } \\
\text { Intervention }\end{array}$ & $\bullet \quad$ Public incubators & $\bullet$ Public (-sponsored) venture capital funds \\
\hline $\begin{array}{l}\text { Intervention } \\
\text { Intect }\end{array}$ & $\begin{array}{l}\text { Promotion of enterprise and } \\
\text { entrepreneurship } \\
\text { Management and skilled workforce } \\
\text { Business incubators, Science and } \\
\text { technology parks, and clusters }\end{array}$ & $\begin{array}{l}\bullet \begin{array}{l}\text { Down-side protection scheme } \\
\text { Tax incentives }\end{array} \\
\text { Fund's operating costs scheme } \\
\text { Tax incentives } \\
\text { Source: compiled by the authors. }\end{array}$ \\
\hline
\end{tabular}

\footnotetext{
${ }^{1}$ See Campbell R. Harvey’s Hypertextual Finance Glossary: http://people.duke.edu/ charvey/Classes/wpg/glossary.htm
} 


\section{Table 3. Advantages and Disadvantages of Tax Credit Schemes}

\begin{tabular}{|l|l|l|}
\hline \multicolumn{1}{|c|}{ Scheme } & \multicolumn{1}{c|}{ Advantages } & \multicolumn{1}{c|}{ Disadvantages } \\
\hline $\begin{array}{l}\text { Volume- } \\
\text { based }\end{array}$ & $\begin{array}{l}\text { Easy to operate and can be exploited irrespective } \\
\text { of when the expenditure is incurred. } \\
\text { Easy to calculate for both companies and tax } \\
\text { authorities }\end{array}$ & $\begin{array}{l}\text { Increased cost to burden on governments, } \\
\text { without the guarantee that companies will } \\
\text { opt to reinvest the value of an incentive in } \\
\text { increased levels of innovation activity }\end{array}$ \\
\hline Incremental & $\begin{array}{l}\text { Focuses the relief on companies that increase } \\
\text { their innovative activity. }\end{array}$ & $\bullet$ Increased complexity of administration \\
\hline \multicolumn{2}{|l|}{ Source: [European Commission, 2001]. } \\
\hline
\end{tabular}

a cap per portfolio [Christofidis, Debande, 2001]. However, a potential pitfall of equity guarantees is that venture capitalists may become less willing to make sound investment decisions.

Credit guarantee schemes may be used in countries where the venture capital industry is not yet developed. Is such economies, financial institutions and commercial banks may be the only source of financing for start-ups and technology firms. Since these companies seldom have a credit history or collateral to back bank loans, credit guarantees compensate banks in the event of a default, reducing their overall transaction risk. In return, governments usually charge a premium [OECD, 1997b]. The main advantages for governments are that credit guarantees limit the need for direct budget allocations, as they are used to encourage borrowers to provide financing to early-stage firms; and that potential borrowers' assessment is completely or partially transferred to the lender. The main problem associated with credit guarantees is the potential for borrowers to become less willing to observe the terms and conditions of loan agreements.

\section{Fiscal Incentives}

Governments can identify specific innovation-related activities and introduce appropriate tax incentives to support them. A study by the European Commission found that the following activities have been selected by a number of governments for targeted fiscal incentive support [European Commission, 2001]:

- Business R\&D expenditure

- R\&D capital expenditure

- Technology transfer

- Industrial design and process engineering

- Implementation of Quality Certificates

- E-commerce, information, and communication technologies

- Software

- Patent applications

- Training of personnel

- Contracting of researchers

- Cooperation between firms and research institutes/universities

- Share ownership at new or innovative firms.

Some tax incentives aimed at supporting the general business environment may also promote innovation indirectly by reducing the obstacles impeding the innovative process. These incentives may foster relevant aspects related to innovation, including the training of staff, the contracting of researchers, the cooperation between firms and research institutes or universities, the creation or financing of innovative firms, and the encouragement of share ownership in innovative firms [European Commission, 2001].

The majority of the tax incentives for innovation activities are included in the corporation tax regimes of each country. Companies are usually allowed to write off all current expenditure on R\&D against their taxable profits in the year the expenditure was made. To further reduce the cost of innovation, the following incentives are also used: extra tax allowances, allowing firms to deduct more than $100 \%$ of their innovation expenditure from their tax base; tax credits; and special depreciation rules [European Commission, 2001].

A tax credit allows a firm to deduct a percentage of their innovation expenditure from their tax base. In a volume-based (flat rates) scheme, all expenditure incurred over a fiscal year is considered for the credit. In an incremental scheme, only expenditure increases over a pre-determined level are rewarded. Mixed schemes, with both volume-based and incremental measures may also be put in place. Table 3 offers a summary of the advantages and disadvantages of each scheme [European Commission, 2001].

Special depreciation rules allow larger sums of innovation-related asset values to be written off earlier in their useful lives. Free depreciation allows companies to deduct up to $100 \%$ of their asset value immediately. Accelerated depreciation enables larger percentages of the asset value to be written off in earlier years. 
Table 4. Advantages of Financial and Fiscal Incentives

\begin{tabular}{|l|l|}
\hline \multicolumn{1}{|c|}{ Type of Incentive } & \multicolumn{1}{c|}{ Advantages } \\
\hline Financial (non-fiscal) & $\begin{array}{l}\text { Fine-tuning within the economy. } \\
\text { Complete control over expenditures }\end{array}$ \\
\hline Fiscal & $\begin{array}{l}\text { Aseful for countries with high innovative performance } \\
\text { Mays the market to decide which sectors present the greatest opportunities for future business success } \\
\text { - Administrative burden shifted to the companies } \\
\text { - Particularly useful for countries with low innovative performance }\end{array}$ \\
\hline \multicolumn{2}{|l}{ Source: compiled by the authors. } \\
\hline
\end{tabular}

Fiscal incentives outside of corporation tax are normally offered through one of the following mechanisms [European Commission, 2001]:

- A reduction on the tax rate levied on capital gains

- A deferral on capital gains deduction payment

- A partial or total exemption of capital gains

- Favorable treatment for dividends from specific venture capital investments

- Favorable treatment within personal income tax of researchers.

\section{Financial vs. Fiscal Incentives}

The main difference between financial and fiscal incentives is that financial incentives allow the government to choose which activities to prioritize, while fiscal incentives enable the market to decide which activities present the greatest opportunities for future success.

According to a study by the European Commission [European Commission, 2001], in countries with relatively low national innovation performance, governments tend "to prioritize incentives that seek to stimulate activity across the whole economy, as opposed to within specific sectors". Fiscal incentives thus have the advantage of allowing the market to decide on fund allocation. On the other hand, in countries with a relatively high national innovation performance, "the preferred method of incentive support is through financial aids, which allow governments to choose those sectors or technologies which they wish to prioritize".

The advantages of each incentive are summarized in Table 4 [European Commission, 2001]. Table 5 summarizes the factors to be considered when designing some financial and fiscal incentives.

\section{Table 5. Factors to be Taken into Account when Designing Financial and Fiscal Incentives for STI}

\begin{tabular}{|c|c|}
\hline Tools & Factors \\
\hline Government loans & $\begin{array}{l}\text { - } \text { Debt service capability } \\
\text { - } \\
\text { Pimiting government financing share } \\
\text { - } \text { Critical interest rates } \\
\text { - Private sector leverage } \\
\end{array}$ \\
\hline $\begin{array}{l}\text { Government venture } \\
\text { capital programmes }\end{array}$ & 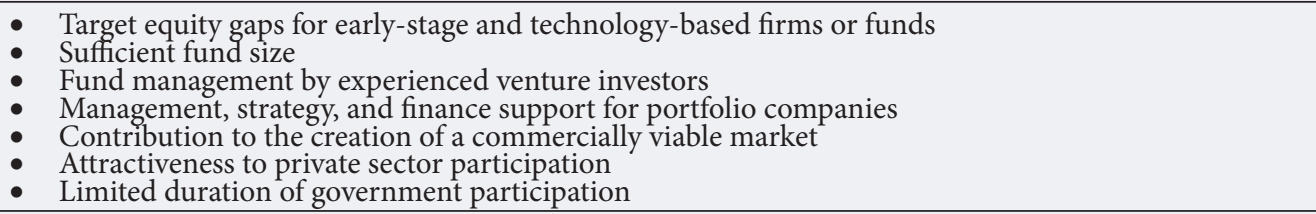 \\
\hline Equity guarantees & $\begin{array}{l}\text { - Risk sharing } \\
\text { - } \\
\text { - } \\
\text { - }\end{array}$ \\
\hline $\begin{array}{l}\text { Government } \\
\text { loan guarantee } \\
\text { programmes }\end{array}$ & $\begin{array}{ll} & \text { Risk sharing with lenders } \\
\text { - } & \text { Types of loans to be guaranteed } \\
\text { - Personal guarantee/personal stake required } \\
\text { - Project appraisal }\end{array}$ \\
\hline Fiscal incentives & $\begin{array}{l}\text { - Fiscal policy involves trade-offs between varying goals and priorities } \\
\text { - Support should not be given to individual innovative activities Activities outside of R\&D, such as } \\
\text { - } \quad \text { Unnambigy transfer, training, and contracting of researchers should not be neglected } \\
\text { - Unambal fiscal legislation, clearly defining the activities that will be supported by each incentive }\end{array}$ \\
\hline
\end{tabular}




\section{Table 6. Financing Instruments by Activity}

\begin{tabular}{|c|c|}
\hline Activity & Type \& Source of Financing \\
\hline Pre-investment and development costs & $\begin{array}{l}\text { - Risk capital from project sponsors } \\
\text { - Pre-investment Fund }\end{array}$ \\
\hline Bidding and procurement & $\begin{array}{ll} & \text { Risk capital from project sponsors } \\
\text { - } & \text { Financial support from government } \\
\end{array}$ \\
\hline $\begin{array}{l}\text { Financial structuring and development of the } \\
\text { security package }\end{array}$ & $\begin{array}{l}\text { Equity capital from project sponsors, investors and dedicated funds and bonds } \\
\text { - Loans from banks, MDBs, insurance companies, financing brokers, } \\
\text { mezzanine funds providers } \\
\text { - Insurance contracts }\end{array}$ \\
\hline Agreements with institutional and other investors & $\begin{array}{ll}\text { - } & \text { Financial support from government (grants) } \\
\text { Equity capital from institutional and other investors }\end{array}$ \\
\hline Agreements with equipment suppliers & - Long-term loans from export credit agencies for equipment purchase \\
\hline $\begin{array}{l}\text { Agreements with prime contractor and } \\
\text { subcontractors on the cost of construction/ } \\
\text { installation }\end{array}$ & - Short-term loans from commercial banks to finance construction/installation \\
\hline $\begin{array}{l}\text { Financing restructuring as the completion of } \\
\text { construction/installation approaches }\end{array}$ & $\begin{array}{l}\text { - Long-term loans from non-bank financial institutions and specialist } \\
\text { investment funds }\end{array}$ \\
\hline $\begin{array}{l}\text { Financial closing } \\
\text { Start of construction/installation }\end{array}$ & $\begin{array}{l}\text { Drawdown of equity and loan funds } \\
\text { - Financial support from government (grants) }\end{array}$ \\
\hline $\begin{array}{l}\text { Operation } \\
\text { Re-financing }\end{array}$ & $\begin{array}{l}\text { - Working capital from the project company and short-term loans from } \\
\text { commercial banks } \\
\text { - Tinancial support from government (grants) } \\
\text { - Public and corporate bonds } \\
\text { - Stock shares of the project company }\end{array}$ \\
\hline
\end{tabular}

\section{Project Financing}

Project financing may be formally defined as a method of structured financing, with both debt and equity components, which is used to fund individual projects. Project financing is based upon lending and investing based on the cash-flows generated by a project alone, as opposed to on the borrower's balance sheet strength, as in standard corporate lending. Its applicability depends on a detailed evaluation of a project's construction or implementation, operating and revenue risks, and adequate contractual and financial arrangements between investors, lenders, and other parties.

The Project Financing scheme has two components:

- Equity provided by investors or sponsors of the project, their return being dependent upon the success of the project

- Senior debt provided by one or more lenders, this debt having a priority on the project's net operating cash flow.

The financial structuring of a project financing transaction consists in finding the optimum allocation between the debt and equity components. For investors, the higher the leverage of a project, the higher their returns will be.

Sponsors or financing sources in Project Financing transactions include:

- Public-sector financing (public budget)

- Public and commercial banks

- Investors and equity providers (for instance, pension funds)

- Multilateral and bilateral financing institutions

- Bond issuances or capital market investors

- Mezzanine and subordinated debt

- Lease financing

- Vendor financing (Export Credit Agencies - ECA's)

- Users fees

- Product/service sales income

- Arising intellectual property rights (in case of R\&D\&I).

Project Financing requires a robust and sustainable stream of revenues to balance financial inputs and outputs, thereby supporting the repayment of expected equity returns and debt service. In STI projects, the main sources of revenues are Arising Intellectual Property (AIP) rights and co-sharing in the commercialization and exploitation of the research results, which are embodied in trading products or services. 
Table 7. Parameters of the Main Contracts, Arranged by the Project Company

\begin{tabular}{|l|l|l|}
\hline \multicolumn{1}{|c|}{ Type of agreement } & Counterpart & \multicolumn{1}{c|}{ Defined issues } \\
\hline $\begin{array}{l}\text { Project or Concession } \\
\text { Agreement }\end{array}$ & Government & $\begin{array}{l}\text { Governance, conditions, rights and risk allocation and } \\
\text { mitigation }\end{array}$ \\
\hline Stakeholders Agreement & Sponsors & $\begin{array}{l}\text { Core activity, corporation form, responsibilities and } \\
\text { liabilities, and internal regulations }\end{array}$ \\
\hline Source: compiled by the authors.
\end{tabular}

Financing and cash flow arrangements occur during the economic life of the project, where their availability and employment serve to make the project viable and funded throughout. Table 6 provides a list of types and sources of financing by activity.

In Project Financing transactions, a special purpose company, the Project Company, is usually set-up for implementing the project. Such company "will act as a borrower under the underlying financing agreements and will be party to a number of other project-related agreements" [EIB, n.d.]. This framework constitutes a security package for managing performance and risks involved in arranging the financing structure.

The project company signs a minimum of two main contracts whose characteristics are depicted in Table 7. The entering of other ancillary contracts depends upon the substance and context of the project. Figures 1 and 2 depict a typical Project Financing structure.

The government is responsible for defining the envisaged project and the concession or project agreement is awarded based on competitive bidding. Such a process emerged in the infrastructure and industrial sectors as a form of public-private partnership and is therefore a reflection of the experience and needs of such sectors.

The application of Project Financing schemes to STI was introduced by the Government of the United Kingdom in the 1990s with the implementation of the Private Finance Initiative ("PFI") in the sector of Education (schools, universities, and libraries) and Research (laboratories, science and technology parks, offices, and industrial parks). According to HM Treasury "PFI was introduced in order to engage the private sector in the design, build, finance, and operation of public infrastructure, with the aim of delivering good quality and well-maintained assets that provide value for money for the taxpayer." [HM Treasury, 2015].

A study by the OECD [OECD, 2014] analyzed various forms of strategic public-private partnerships and identified the reasons for their increased popularity in the STI sector. As noted in the study, "traditionally used for physical infrastructure, PPPs are increasingly popular in R\&D and innovation policy because they are perceived as a more adaptive tool than traditional subsidies for achieving such objectives in an environment in which the nature of $R \& D$ and innovation processes is changing (e.g., increased usercentered content, higher dependency on external sources of knowledge and know-how, as illustrated by open innovation approaches), and business R\&D strategies and social needs are rapidly evolving (e.g., ageing population, the environment, sustainable cities). Finally, PPPs are a useful policy tool in demand-side innovation policy such as the public procurement of innovation or in efforts to foster smart specialization strategies in regions."

\section{Figure 1. Cash Flows among Project Financing Parties}

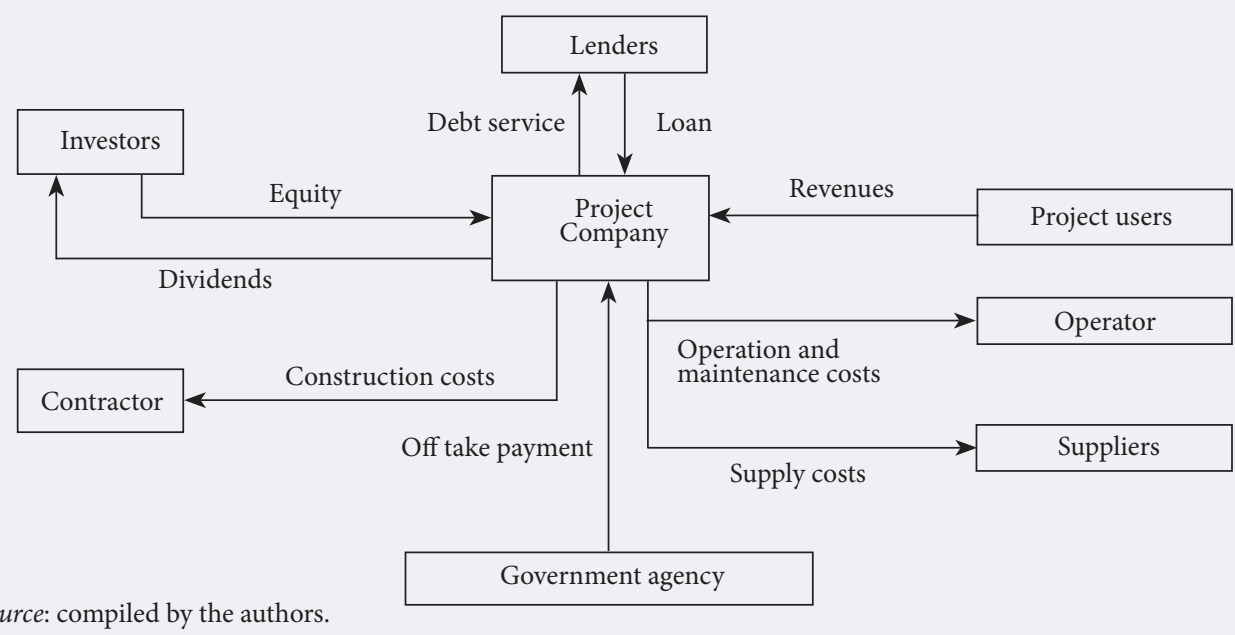




\section{Figure 2. Typical Structure of a Project Financing Scheme}

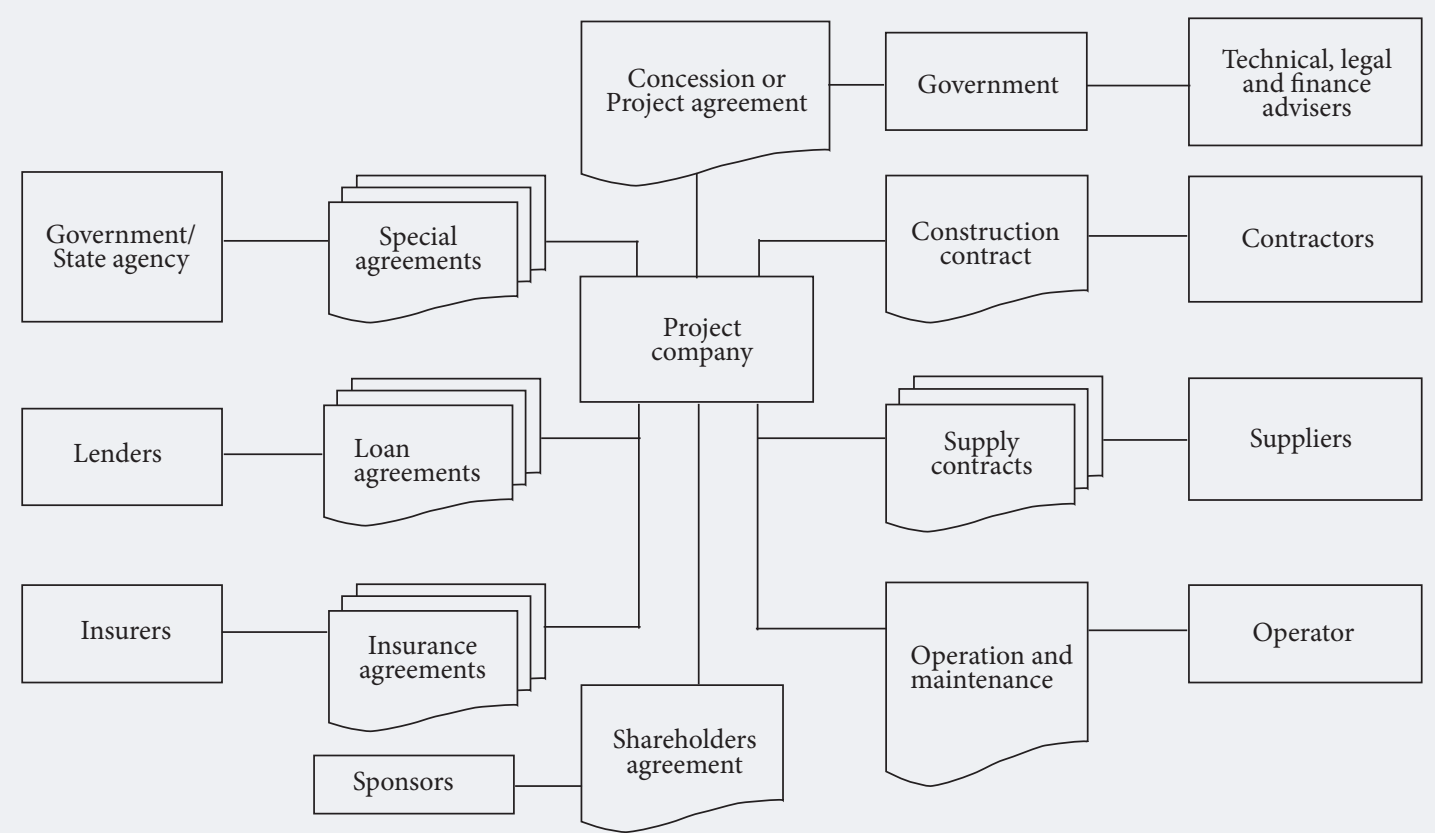

Source: compiled by the authors based on [UNIDO, 1996].

It is worth noting that a wide range of public-private partnerships definitions are available and many forms of PPPs have been used in the STI sector. This section, however, is focused on Project Financing as the main PPP financing instrument.

The same study by the OECD [OECD, 2014] also indicated the critical factors for Project Financing implementation, as follows:

- "Partnership implies some sharing of costs, risks, and benefits between participants"

- Intellectual property rights should be shared both in upstream research and downstream commercialization, including residual rights

- Seek to promote the participation of knowledge-based SMEs

- Support for international and cross-border research programs should be given

- Project design, award, and implementation should be on a competitive basis

- Seek financial sustainability, including measures to counter the tendency to underinvest as well as undue practices.

According to the authors of the aforementioned OECD report, focus should be given (i) to areas where the collaboration between the government and the private sector is essential, such as in healthcare,

\section{Figure 3. Total R\&D Expenditure by Source of Financing: UK 2000-2015 (billion $\mathfrak{E}$ )}

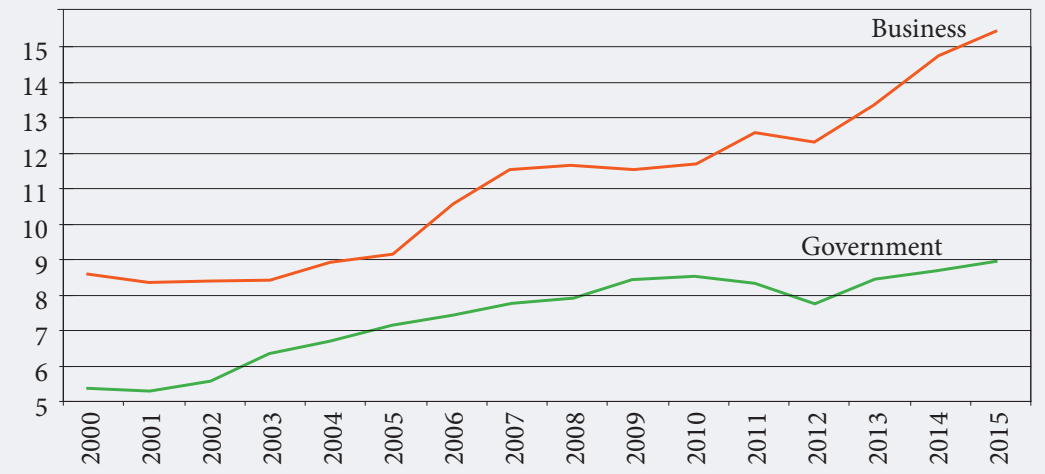

Source: [European Commission, 2015]. 
sustainable transportation, and environment protection; (ii) to business access to research infrastructure and achievements in public research; and (iii) to reducing technological and financial risks upstream;

\section{STI Financing in Practice}

The extension and grade of application in practice of those finance instruments discussed here will be revealed in two selected countries with sophisticated and complex national innovation systems, though they are at different stages of experience and development. In this paper, we will study the cases of the United Kingdom and Brazil. The application analysis presented below indicates the modes of financing, their potential and limits as well as possible combinations to enhance their viability and effectiveness.

\section{UK: PFI in practice}

In the United Kingdom, the predominance of the business sector in financing STI has further expanded over the course of the last decade. Figure 3 indicates how far the business sector has been overtaking the government on expenditures in STI over the years.

The distribution and flows of funds in the country has become highly complex and diffuse, showing the prevalence of the business sector, as presented in the Figure 4.

The increased participation of the business sector in supporting STI in the UK could make the efforts and schemes more relevant and viable for strengthening the cooperation between public and private sector in order to promote a focus in STI areas of public interest, such as healthcare, sustainable transport, and environmental protection. It may also facilitate businesses' access to research infrastructure and achievements in public research and reduce technological and financial risks in high capital investment research endowments. In this context, one can observe a number of funding initiatives based on the models proposed by the UK Private Financing of Infrastructure - PFI. The Department of Energy and Climate Change (DECC) is one of the agencies in the country promoting the PFI scheme for STI funding. Figure 5 illustrates the DECC projects' financing model.

Project financing in this model is applied to provide funding to consolidate the efforts of making projects commercially viable using the declining cost of capital to one's advantage.

Another interesting example of the use of PFI under a Public-Private Partnership arrangement is the Energy Technology Institute (ETI) sponsored by the Secretary of State for Business, Innovation, and Skills (SSBIS). The main characteristics of this scheme are indicated in Table 8.

The main idea of the creation of the ETI is to consolidate and improve strong operational links between academia, industry, and government on targeted R\&D projects.

Figure 6 presents the ETI arrangement structure and the flow of funds.

\section{Figure 4. STI Funding Framework in the UK: 2012 (million $\mathfrak{E}$ )}

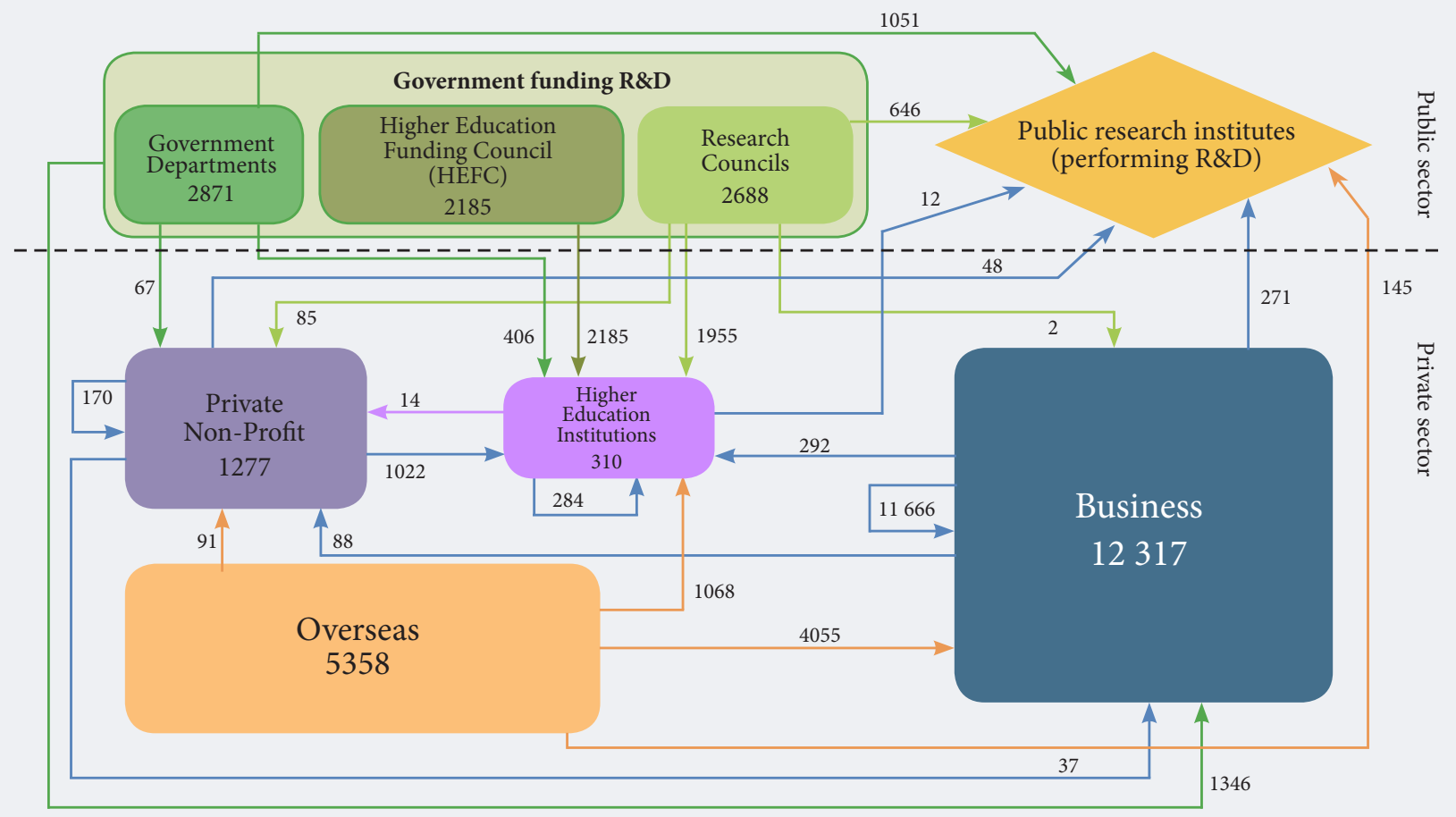

Source: [European Commission, 2015]. 


\section{Figure 5. DECC-UK projects financing model}

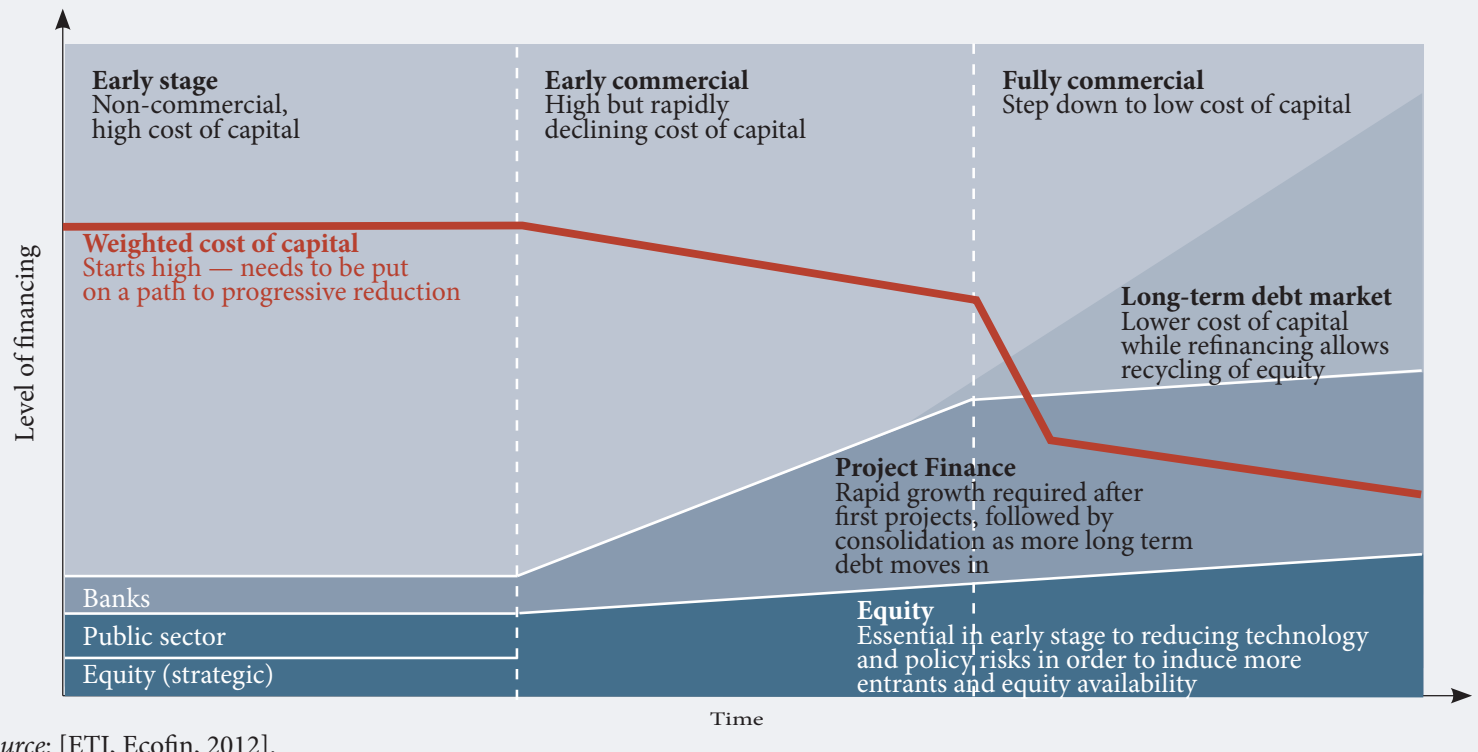

Source: [ETI, Ecofin, 2012].

\section{Table 8. Basic characteristics of the ETI}

\begin{tabular}{|l|l|}
\hline \multicolumn{1}{|c|}{ Item } & \multicolumn{1}{c|}{ Characteristics } \\
\hline Concept & The ETI is a Public-Private Partnership between global energy and engineering companies and the UK Government \\
\hline Constitution & ETI is the core node constituted as a Limited Liability Partnership, formed by a consortium of companies \\
\hline Role & $\begin{array}{l}\text { To act as a conduit between academia, industry, and the government to accelerate the development of low carbon } \\
\text { technologies }\end{array}$ \\
\hline Objective & $\begin{array}{l}\text { To bring together engineering projects that develop affordable, secure, and sustainable technologies to help the UK } \\
\text { address its long term emissions reduction targets as well as delivering nearer term benefits }\end{array}$ \\
\hline Action & $\begin{array}{l}\text { It makes targeted commercial investments in nine technology programs across heat, power, transport, and the } \\
\text { infrastructure that links them }\end{array}$ \\
\hline Source: [ETI, 2012].
\end{tabular}

\section{Figure 6. ETI Partnership and Financing Framework}

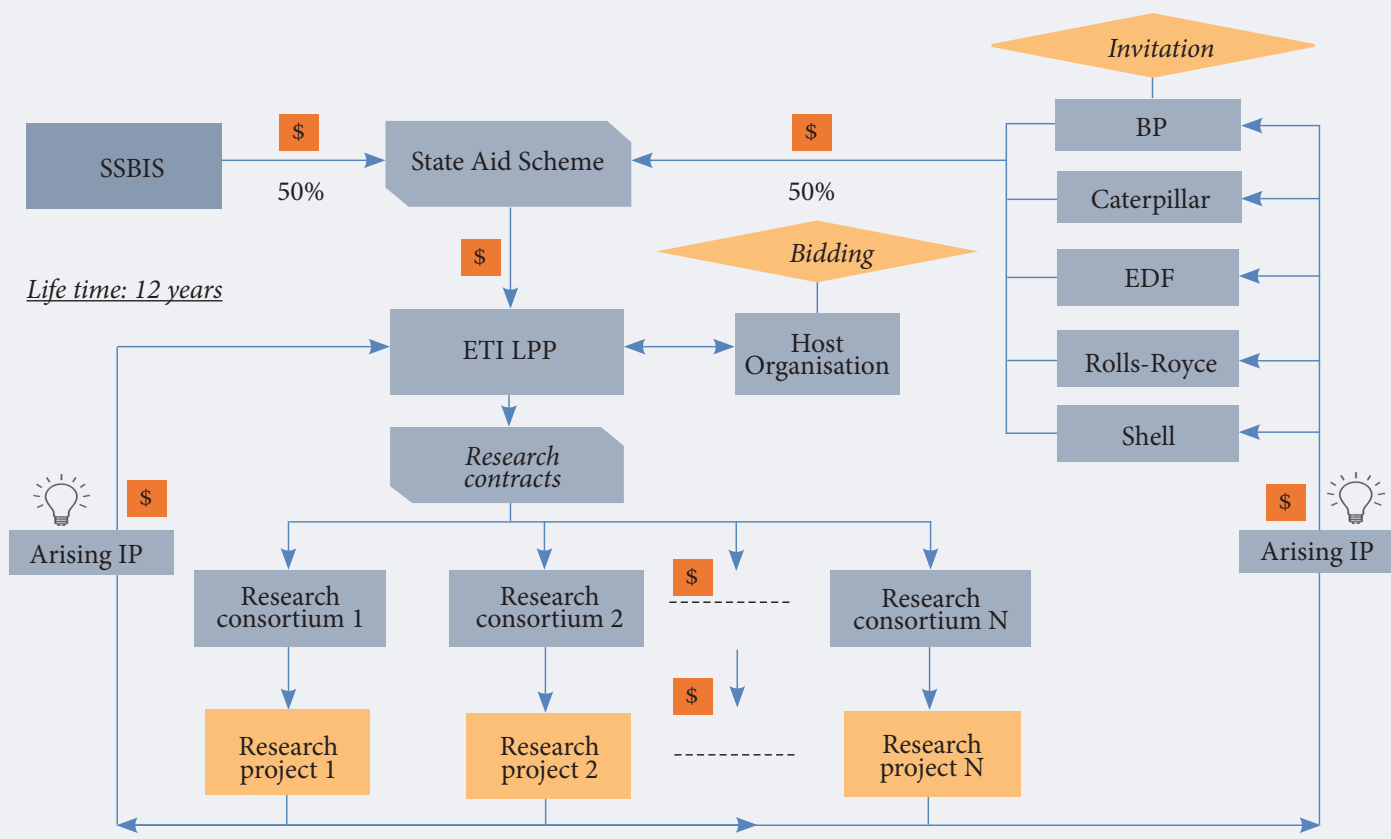

Source: compiled by the authors. 


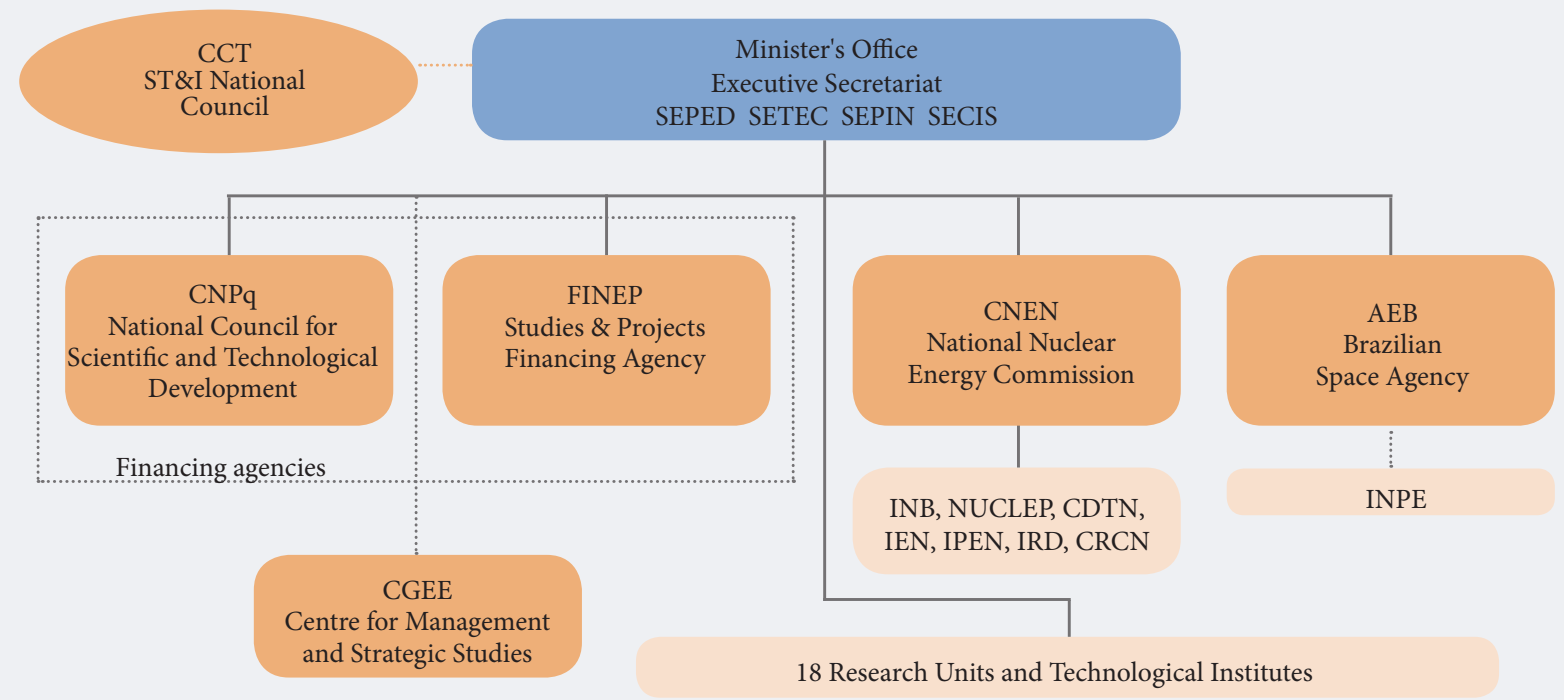

Note: INB is a group of companies Indústrias Nucleares do Brasil; NUCLEP is a company Nuclebrás Equipamentos Pesados. For definitions of other acronyms see Table 9.

Source: [Leitão, 2010].

Following a general description of a PPP/PFI framework, the core and special purpose institution in this case is the Energy Technology Institute (ETI) LLP ${ }^{2}$, registered as a Limited Liability Partnership in the United Kingdom ${ }^{3}$. The mobilized founding members, constituting the ETI LLP, under a State Aid Scheme ${ }^{4}$, are: from the Public Sector, the Secretary of State for Business, Innovation and Skills (SSBIS); from the Private Sector, a consortium formed by British Petroleum (BP), Caterpillar, EDF Energy, RollsRoyce, and Shell International. Hitachi jointed joined a program associated with the scheme. Through competitive bidding, a host institution was selected to provide research facilities, offices, and infrastructure for the ETI management and support staff. The winning bidder was the Midlands Consortium, which is comprised of the Universities of Birmingham, Loughborough, and Nottingham with financial support from Advantage West Midlands and the East Midlands Development Agency. The main location of ETI is at Loughborough University, on the Holywell Park area of the campus, at the heart of the University's Science and Enterprise Park.

On the basis of a research agenda defined and monitored by the core members of ETI, R\&D projects are procured through competitive bidding by centers of excellence across the United Kingdom and overseas, organized in consortia consisting of SMEs and large enterprises, universities, and other expertise organizations. R\&D projects shall refer to IPR arrangements and focus on the commercial deployment of their results.

Regarding funding, funds are provided on a 50:50 basis by the public and private sectors and they are supposed to be allocated to the best R\&D projects. The expected revenues for the ETI and the private sector members are the contractual definition of Arising Intellectual Property Rights and the eventual results of commercial deployment.

\section{Brazil: Funding STI via Sector Funds}

The Brazilian government, motivated by and in consultation with the private sector, launched a comprehensive set of fiscal measures in 1999 to channel financial contributions from the private and manufacturing sectors, known as STI Sectorial Funds. Traditionally in Brazil STI has been almost fully funded by the public sector. Indeed, the role of the state in Brazil in both the financing and execution of STI activities is highly determinant and even dominant. Presently, the Ministry of Science, Technology, Innovation, and Communication (MCTIC) $)^{5}$ is directly responsible for the most important actors, such as promotion agencies, major R\&D institutes and units as well as sectorial technological institutes (Figure 7).

\footnotetext{
${ }^{2}$ http://www.eti.co.uk/about

${ }^{3}$ Under the Limited Liability Partnership Act 2000 (https://www.legislation.gov.uk/ukpga/2000/12/contents)

${ }^{4}$ https://d2umxnkyjne36n.cloudfront.net/documents/Summary-of-Scheme-for-GBER.pdf?mtime=20160912110613

${ }^{5}$ Name in Portuguese - Ministério da Ciência, Tecnologia, Inovações e Comunicações. Previous names - Ministry of Science and Technology (Ministério da Ciência e Tecnologia, MCT) (until August 2011); Ministry of Science, Technology and Innovation (Ministério da Ciência, Tecnologia e Inovações, MCTI) (until May 2016).
} 


\section{Figure 8. Overview of the Brazilian System of Research and Innovation}

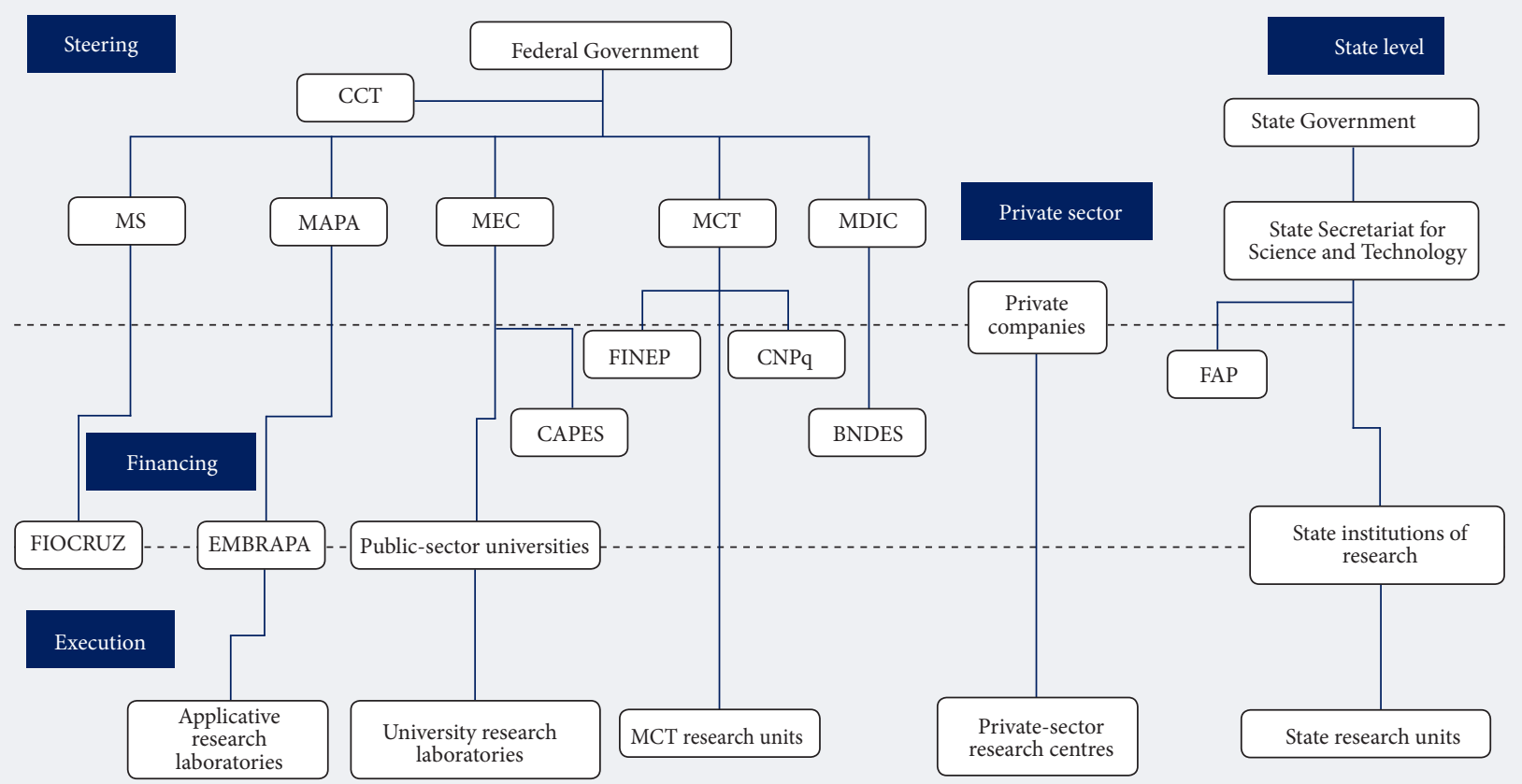

Note: For definitions of all acronyms see table 9.

Source: S\&T Landscape Brazil, Access4.EU. Available at: http://www.access4.eu/brazil/330.php, accessed 12.11.2017.

Figure 8 indicates the overall picture of the Brazilian STI system. The private R\&D sector is practically an isolated sector. At the state level, the same framework is reproduced.

Regarding the actual allocations from the state, after significant growth observed in the 1970s, when they reached an historic high of 800 million Real in the National Fund for Scientific and Technological Development (FNDCT), they dropped steadily to between 80 to 200 million Real in the 1990s. With the advent of the STI Sector Funds in 1999, the allocations returned to a growth trajectory. Figure 9 illustrates such development.

Meanwhile, the FNDCT, supplemented by the STI Sector funds, became the major financial source of support for Brazil's STI system. Figure 10 shows the evolution of the FNDCT after the implementation of the STI sector funds.

The STI Sector Funds are designed to follow the Systemic Model of Innovation. Their main policy goals can be summarized as follows:

\section{Figure 9. Evolution of the Allocations}

from the Brazilian National S\&T Fund

(FNDCT) between 1970 and 2006

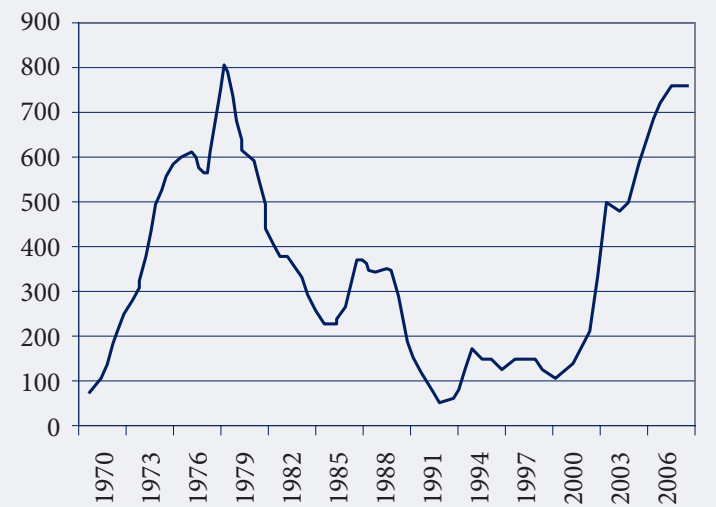

Note: values in constant Real adjusted by the annual consumer price index (IPCA)

Source: [do Canto, 2007].

\section{Figure 10. Evolution of the FNDCT Expenditures in 2000-2012 (current R $\$$ billion)}

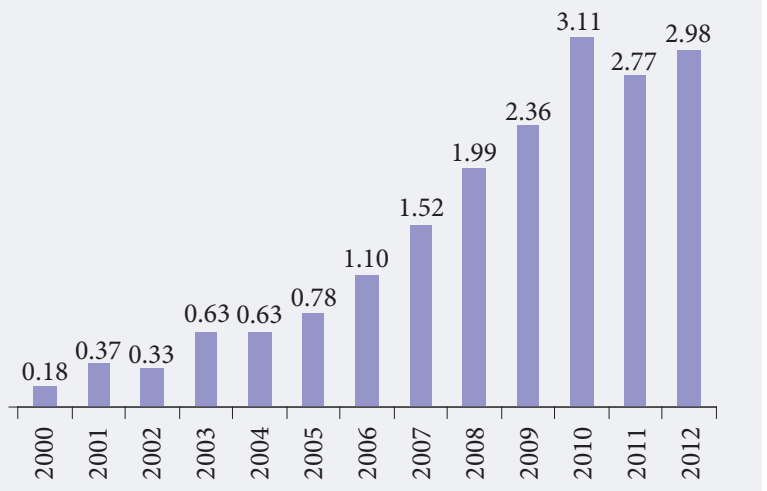

Source: compiled by the authors по данным MCTIC. 
Table 9. Definitions of Acronyms of Brazilian Organizations and Institutional Terms Mentioned in Figures 7 and 8

\begin{tabular}{|c|c|c|}
\hline Acronym & Name in Portuguese & Name in English \\
\hline AEB & Agência Espacial Brasileira & Brazilian Space Agency \\
\hline BNDES & $\begin{array}{l}\text { Banco Nacional de Desenvolvimento Econômico } \\
\text { e Social }\end{array}$ & Brazilian Development Bank \\
\hline CAPES & $\begin{array}{l}\text { Coordenação de Aperfeicoamento de Pessoal de } \\
\text { Nível Superior }\end{array}$ & $\begin{array}{l}\text { Coordination Commission for the } \\
\text { Improvement of Personnel's Qualifications in } \\
\text { the Higher Education Sector }\end{array}$ \\
\hline CCT & Conselho Nacional de Ciência e Tecnologia & National Council for Science and Technology \\
\hline CDTN & $\begin{array}{l}\text { Centro de Desenvolvimento da Tecnologia } \\
\text { Nuclear }\end{array}$ & $\begin{array}{l}\text { Center for the Development of Nuclear } \\
\text { Technology }\end{array}$ \\
\hline CGEE & Centro de Gestão e Estudos Estratégicos & Center for Strategic Management and Studies \\
\hline CNEN & Comissão Nacional de Energia Nuclear & National Nuclear Energy Commission \\
\hline $\mathrm{CNPq}$ & $\begin{array}{l}\text { Conselho Nacional de Desenvolvimento } \\
\text { Científico e Tecnológico }\end{array}$ & $\begin{array}{l}\text { National Council for Scientific and } \\
\text { Technological Development }\end{array}$ \\
\hline $\mathrm{CRCN}$ & $\begin{array}{l}\text { Centro Regional de Ciências Nucleares do } \\
\text { Nordeste }\end{array}$ & Nuclear Sciences Regional Center, North-East \\
\hline EMBRAPA & Empresa Brasileira de Pesquisa Agropecuária & Brazilian Agricultural Research Corporation \\
\hline FAP & Fundação de Apoio à Pesquisa & State Funding Agency \\
\hline FINEP & Financiadora de Estudos e Projetos & Funding Authority for Studies and Projects \\
\hline FIOCRUZ & Fundação Oswaldo Cruz & Oswaldo Cruz Foundation \\
\hline IEN & Instituto de Engenharia Nuclear & Nuclear Engineering Institute \\
\hline INPE & Instituto Nacional de Pesquisas Espaciais & The National Institute for Space Research \\
\hline IPEN & Instituto de Pesquisas Energéticas e Nucleares & Nuclear and Energy Research Institute \\
\hline IRD & Instituto de Radioproteção e Dosimetria & $\begin{array}{l}\text { Institute of Radiation Protection and } \\
\text { Dosimetry }\end{array}$ \\
\hline MAPA & $\begin{array}{l}\text { Ministério da Agricultura, Pecuária e } \\
\text { Abastecimento }\end{array}$ & Ministry of Agriculture, Livestock and Supply \\
\hline MDIC & $\begin{array}{l}\text { Ministério da Indústria, Comércio Exterior e } \\
\text { Serviços }\end{array}$ & $\begin{array}{l}\text { Ministry of Industry, Foreign Trade and } \\
\text { Services }\end{array}$ \\
\hline MEC & Ministério da Educação & Ministry of Education \\
\hline MS & Ministério da Saúde & Ministry of Health \\
\hline SECIS & Secretaria de Inclusão Social & Secretariat for Social Inclusion \\
\hline SEPED & $\begin{array}{l}\text { Secretaria de Políticas e Programas de Pesquisa e } \\
\text { Desenvolvimento }\end{array}$ & Secretariat for R\&D Policies and Programs \\
\hline SEPIN & Secretaria de Política de Informática & Secretariat for Informatics Policy \\
\hline SETEC & $\begin{array}{l}\text { Secretaria de Desenvolvimento Tecnológico e } \\
\text { Inovação }\end{array}$ & $\begin{array}{l}\text { Secretariat for Professional and Technological } \\
\text { Education }\end{array}$ \\
\hline
\end{tabular}

- to increase and promote the stability of financial resources allocated to the STI system;

- to promote the manufacturing sector;

- to create an institutional environment conducive to the shared management of funds by the relevant government agencies (Finep and $\mathrm{CNPq}$ ) and the private sector.

The resources of the Sector Funds come from different federal taxes and contributions of selected sectors, such as oil and gas (being the highest input), healthcare, agribusiness, energy, and aeronautics:

- The state share of profit derived from the exploitation of natural resources (for example $0.75 \%$ to $1 \%$ of the net profit of concessionary companies involved in the generation, transmission, and distribution of electricity),

- The share of the tax on industrialized products (IPI) for certain sectors (at least $43 \%$ for the goods and products benefiting from the Informatics $\mathrm{Law}^{6}$ )

- The share (7.5\% to $17.5 \%)$ of payments for the Contribution for Intervention in the Economic Domain (CIDE) on the values that pay off the use or acquisition of technological knowledge or technology transfer from abroad (service payment, royalties, specialized technical, or professional services).

The acquired resources are allocated by the National Fund for Scientific and Technological Development (FNDCT) and managed by two agencies: the National Council for Scientific and Technological Development (CNPq) and the Funding Authority for Studies and Projects (Finep). The resources are dedicated to

${ }^{6}$ http://www.institutoslactec.org.br/en/submenu-ped/lei-de-informatica/ 
Table 10. FNDCT's Budget Breakdown (2013)

\begin{tabular}{|l|l|}
\hline \multicolumn{1}{|c|}{ Cost items } & \multicolumn{1}{c|}{ Current RS Million } \\
\hline Total FNDCT & 3056.1 \\
\hline Support to R\&D in universities and research institutions & 2004.9 \\
\hline Scholarships (Science without Borders Program) & 307.6 \\
\hline S\&T Infrastructure & 367.0 \\
\hline Equalization & 308.3 \\
\hline Grants to firms & 345.0 \\
\hline Support to MCTI research institutions & 320.1 \\
\hline Other actions & 77.8 \\
\hline Source: [FNDCT, 2013]. & \\
\hline
\end{tabular}

14 subjects and two interdisciplinary fields: Aeronautics, Agribusiness, Amazon Region, Waterways, Biotechnology, Energy, Space, Water Resources, Information Technology, Infrastructure, Minerals, Oil and Natural Gas, Health, Transportation, "Yellow Green Technologies", and Telecommunications.

Table 10 presents the distribution of the resources allocated by the FNDCT in 2013.

\section{Recent and Future Trends}

The contribution of science, technology, and innovation is expected to remain a vital pillar for economic and social development. As costs related to the infrastructure and production of scientific and technological advances are expected to rise steadily, modern and robust financing instruments are indispensable for adequately supporting STI efforts and overcoming financing difficulties. A study by the United Nations Framework on Climate Change (UNFCCC) [UN, 2009] reviewed the financial barriers at each stage of technological development and proposed different financing schemes available to overcome such obstacles. Table 11 summarizes the main findings of this study.

A discussion about recent and future STI financing trends follows below.

\section{Systemic Approach}

Although there is a consensus among experts that the linear approach for modelling and financing STI infrastructure and efforts is no longer appropriate or efficient for generating new sources of knowledge and know-how, nor is it viable for making new products and services available, much more effort is needed in order to fully develop systemic models and practices.

In STI financing, much of the attention and prioritization of different actors still follows a linear model, where public funds are dedicated primarily to basic research, while business expenditures are directed towards applied R\&D and commercialization. Only through taxes and subsidies are business R\&D expenditures relevant in basic research.

Moreover, the different stages of STI (basic-applied-development) are increasingly interdependent and overlapping. To overcome such difficulties, a major drive will include consolidating the STI stages, environments, actors, and sponsors into dedicated programs, which deal with specific products, as opposed to a central theme. Here, the concepts of clusters, nodes of excellence, and value chains will play important roles. Research-supporting programs from the European Union, Organization for Economic Cooperation and Development (OECD) and United Nations specialized agencies are fair examples of this systemic approach trend.

\section{Strategic Role of Governments via Grants and Fiscal Incentives}

Governments can be expected to remain a major supporter of STI development for at least two reasons. The first reason involves the responsibility of the public sector in enhancing, gathering, and protecting knowledge and culture. Here, the main public duty is to guarantee that the necessary institutional and infrastructural foundation of a sustainable national innovation system is in place. Access to STI efforts, including their results, should be granted both for people and businesses. The second reason relates to the state's responsibility in mobilizing scientific and technological knowledge to address issues of the general well-being of its population. Such public responsibilities shall continue as strong justifications for allocating government budgetary funds and maintaining tax and other non-fiscal incentives for the support of STI initiatives.

\section{International Funding and Project Preparation}

While the internationalization of STI has become very relevant, only a few international funding mechanisms have been established and coordination between countries remains insufficient. The development of some of mechanisms such as the Kyoto and Montreal Protocols might be an interesting vector for the further creation and expansion of global funding schemes. 
Table 11. Financing Barriers and According Funding Instruments by Stage of Technological Maturity

\begin{tabular}{|c|c|c|c|c|}
\hline \multirow{2}{*}{$\begin{array}{c}\text { Stages of } \\
\text { technological } \\
\text { maturity }\end{array}$} & \multirow{2}{*}{$\begin{array}{l}\text { Category of } \\
\text { barriers }\end{array}$} & \multicolumn{2}{|c|}{ Financing barriers } & \multirow{2}{*}{$\begin{array}{l}\text { Financing vehicles and } \\
\text { schemes }\end{array}$} \\
\hline & & Public finance & Private finance & \\
\hline I & $\begin{array}{l}\text { Proof of } \\
\text { concept }\end{array}$ & $\begin{array}{l}\text { - Other political priorities for } \\
\text { public finance } \\
\text { - Unclear results of fundamental } \\
\text { research (difficult to monitor, } \\
\text { report, and verify) } \\
\text { - Unclear results of education } \\
\text { and training (difficult to } \\
\text { monitor, report, and verify) }\end{array}$ & $\begin{array}{l}\text { - Insufficient rate of return } \\
\text { - Spill-over effects prevent private } \\
\text { financiers from capturing the } \\
\text { benefits of investment }\end{array}$ & $\begin{array}{l}\text { - R\&D support } \\
\text { - R\&D grants } \\
\text { - Crowd financing } \\
\text { - Tax credits }\end{array}$ \\
\hline I & Technical & $\begin{array}{l}\text { - Other political priorities for } \\
\text { government budgets and } \\
\text { public finance }\end{array}$ & $\begin{array}{l}\text { - Lack of good technical } \\
\text { information, resulting in high-risk } \\
\text { profiles } \\
\text { - Spill-over effects prevent private } \\
\text { financiers from capturing the } \\
\text { benefits of investment }\end{array}$ & - $\mathrm{R} \& \mathrm{D}$ grants \\
\hline I, II & Scale & $\begin{array}{l}\text { - Relatively high costs to scale up } \\
\text { from prototype }\end{array}$ & $\begin{array}{l}\text { - Lack of technological track record, } \\
\text { resulting in high-risk profiles }\end{array}$ & $\begin{array}{l}\text { - Angel investors } \\
\text { - Innovation prizes } \\
\text { - Incubators } \\
\text { - Public/Private VC fund }\end{array}$ \\
\hline I, II, III & Costs & $\begin{array}{l}\text { - High costs to reach significant } \\
\text { deployment }\end{array}$ & $\begin{array}{l}\text { - Lack of policy to overcome costs, } \\
\text { leading to low IRR }\end{array}$ & $\begin{array}{l}\text { - Venture capital } \\
\text { - Public/private equity } \\
\text { fund } \\
\text { - Soft loans } \\
\text { - International project } \\
\text { development mechanism }\end{array}$ \\
\hline I, II, III, IV & Economic & $\begin{array}{l}\text { - Unwillingness to interfere in } \\
\text { the market, especially when } \\
\text { drastic changes harm vested } \\
\text { interests } \\
\text { - Inflexibility of tax policy }\end{array}$ & $\begin{array}{l}\text { - Energy pricing and subsidies; } \\
\text { insufficient carbon price } \\
\text { - High upfront capital costs } \\
\text { - Lack of valuation of co-benefits, } \\
\text { leading to low IRR } \\
\text { - Requirement of large parallel } \\
\text { infrastructure, leading to high } \\
\text { upfront costs }\end{array}$ & $\begin{array}{l}\text { - Equity } \\
\text { - Mezzanine finance } \\
\text { - Debt } \\
\text { - PPPs } \\
\text { - Public procurement } \\
\text { - Guarantees } \\
\text { - International investment } \\
\text { facilitation }\end{array}$ \\
\hline I, II, III, IV & Social & $\begin{array}{l}\text { - Vested interests in social/ } \\
\text { consumer preferences } \\
\text { - Underinvestment in education } \\
\text { and training }\end{array}$ & $\begin{array}{l}\text { - Lack of a consumer or user } \\
\text { market } \\
\text { - Split incentives (principal-agent } \\
\text { problem) } \\
\text { - Lack of labor skills }\end{array}$ & $\begin{array}{l}\text { - Loan facilities } \\
\text { - Credit lines }\end{array}$ \\
\hline I, II, III, IV & Institutional & $\begin{array}{l}\text { - Vested interests in institutional } \\
\text { settings } \\
\text { - Public finance policy failures }\end{array}$ & $\begin{array}{l}\text { - Lack of regulatory framework } \\
\text { - Absence of international } \\
\text { standards } \\
\text { - Technology lock-in } \\
\text { - Lack of match between ECA } \\
\text { conditions and local financing } \\
\text { conditions on ESTs }\end{array}$ & $\begin{array}{l}\text { - R\&D Programs } \\
\text { - Systemic financing } \\
\text { - Investment banking } \\
\text { - Research contracting }\end{array}$ \\
\hline V & $\begin{array}{l}\text { Market failures } \\
\text { and transaction } \\
\text { costs }\end{array}$ & $\begin{array}{l}\text { - Lack of recognition of public } \\
\text { role in resolving market } \\
\text { failures and transaction costs } \\
\text { - Vested interests in } \\
\text { bureaucracies }\end{array}$ & $\begin{array}{l}\text { - Inefficient regulatory environment } \\
\text { and bureaucracy } \\
\text { - Lack of risk assessment and } \\
\text { management tools specific to ESTs } \\
\text { - Lack of appropriate financial } \\
\text { - packages } \\
\text { - Lack of awareness and } \\
\text { information } \\
\text { - Imperfect markets } \\
\text { - Technology market failure } \\
\end{array}$ & $\begin{array}{l}\text { - Public procurement } \\
\text { - Private financing and } \\
\text { management }\end{array}$ \\
\hline
\end{tabular}

Project preparation is a field that has grown in importance. Given the difficulties involved in accurately forecasting STI efforts' results (including their monetary returns), as well as the stringent requirements from national and international investors, bankers, and sponsors, STI project developers and managers have increasingly sought finance facilities to support project preparations at the pre-investment phase. Recognizing such a trend, International Financial Institutions (IFI) such as the World Bank [World Bank, 2017], the European Bank for Reconstruction and Development (EBRD), and the Asian Development Bank, have created special Project Preparation Facilities (PPF) to support stakeholders. The expanding use of public and private procurement for awarding R\&D-dedicated resources will also further reinforce such growing demand.

\section{Private Financing and Management}

The emergence of robust technology-based industries has introduced new ways of organizing and managing STI efforts as a whole. The strengthening of private labs and collaborative schemes between 
public and private entities are evidence of such a trend. The experience of the Fraunhofer Society for the Advancement of Applied Research ${ }^{7}$, based in Germany, but active internationally, could also prove a winning example for the future. This organization operates institutes and research units directly or in collaboration with public and private universities and other research institutes, earning its income mostly through contracts with industry or specific government projects.

\section{Investment Banking}

The continuous search for promising, break-through innovative investments has resulted in an increasing number of financial institutions focusing on supporting and investing in research labs, technology companies, and innovation development projects. A number of banking facilities have become available for well-structured STI projects and programs, such as soft loans from development banks, mezzanine debt from syndicate arrangements, long-term debt offers, trust funds, refinancing for maturated R\&D, or the leverage of debt-equity deals.

\section{Public-Private Partnerships}

Successful past experience with PPPs in a number of areas of public and business common-interest should result in their increased use in the STI field. There is a clear trend towards establishing or improving the contractual and legal framework in many countries and internationally among countries. The participation of the World Bank and other international financing institutions has been paving the way for the more intensive use of PPPs in STI in the future. The PPP models used in the United Kingdom are proving to be successful approaches and schemes in the STI area.

\section{Research Contracting with the Prevalence of Intellectual Property Rights}

The impressive development of technology-intensive products and services should give rise to contracting $\mathrm{R} \& \mathrm{D}$ based upon IPR arrangements. The protection of IPRs on a global scale allows for the necessary legal security in establishing consistent R\&D-to-commercialization contracts, with IPRs included as a guarantee in equity and debt financing agreements.

\section{Venture Capital and Business Angels}

Operators within the technology-based industry increasingly seek business angels for financing start-ups and venture capital for supporting their expansion towards maturity.

Private investors purchase shares in new technology-based companies looking for dividends and market valorization. Well-organized stages have been available for investors, comprising seed funds, angel round with access to board sits, series A round and beyond, which are granted by venture capital firms and further on until the issuing of Initial Public Offerings (IPOs).

\section{Crowd Financing and e-Financing}

The steady expansion of internet-based social networks has supported the launch of new financing structures, such as crowd financing and e-financing, which provide resources for deals and projects with common interests, across sectors such as the health, education, mobility, and environmental sectors. Specific areas of STI coverage have unlimited potential for raising funds.

\section{Conclusion}

STI costs have risen, as have government budget restrictions. The STI field has become more complex, collaborative, and network-based, with the private sector also becoming more dependent on innovation for productivity and competitiveness gains. This environment demands more robust and complex solutions, combining both public and private financing. Instruments from venture capital to publicprivate partnerships have gained importance in supporting STI efforts.

After discussing a number of instruments and incentives available to governments for improving their national innovation systems, two case studies demonstrated how government efforts from the United Kingdom and Brazil successfully tackled innovation-financing issues. Lastly, the paper reviewed recent and future STI financing trends.

\section{References}

Christofidis C., Debande O. (2001) Financing Innovative Firms through Venture Capital, Luxembourg: European Investment Bank. Available at: http://www.eib.org/attachments/pj/vencap.pdf, accessed 12.11.2017.

do Canto O.A.M. (2007) Incentives to Support Innovation in the Private Sector: The Brazilian Experience, Rio de Janeiro: Financiadora de Estudos e Projetos (FINEP). Available at: https://publications.iadb.org/handle/11319/4628, accessed 11.03.2018.

\footnotetext{
${ }^{7}$ https://www.fraunhofer.de
} 
EIB (n.d.) Project Finance. EPEC PPP Online Guide. Available at: http://www.eib.org/epec/g2g/annex/1-projectfinance/, accessed 12.11.2017.

ETI (2012) Delivering the UK's Future Energy Technologies. Annual Review 2012, Loughborough: Energy Technologies Institute. Available at: http://www.all-energy.co.uk/_novadocuments/29285?v=635035415144670000, accessed 12.11.2017.

ETI (2016) State Aid, Loughborough (UK): Energy Technologies Institute. Available at: https://d2umxnkyjne36n. cloudfront.net/documents/Summary-of-Scheme-for-GBER.pdf?mtime=20160912110613, accessed 12.11.2017.

ETI, Ecofin (2012) Mobilising Private Sector Finance for CCS in the UK, Loughborough: Energy Technologies Institute; London: Ecofin Research Foundation. Available at: https://s3-eu-west-1.amazonaws.com/assets.eti. co.uk/legacyUploads/2014/03/Ecofin_CCS_Report1.pdf, accessed 12.11.2017.

European Commission (2001) Corporation Tax and Innovation: Issues at Stake and Review of European Union in the Nineties, Brussels: European Commission. Available at: http://www.cordis.lu/innovation-policy/studies/fi_ study1.htm, accessed 12.11.2017.

European Commission (2015) RIO Country Report 2015: United Kingdom, Brussels: European Commission. Available at: https://rio.jrc.ec.europa.eu/en/library/rio-country-report-united-kingdom-2015, accessed 12.11.2017.

FNDCT (2013) Relatório de Resultados do FNDCT 2013, Rio de Janeiro: FNDCT. Available at: http://www.finep.gov. br/images/a-finep/Fontes_de_Recursos/Relatorio_de_Resultados_FNDCT_2013.pdf, accessed 12.11.2017.

HM Treasury (2015) Private Finance Initiative and Private Finance 2 Projects: 2015 Summary Data, London: Crown.

Hodge G.A., Greve C. (2007) Public-Private Partnerships: An International Performance Review. Public Administration Review, vol. 67, pp. 545-558. DOI: 10.1111/j.1540-6210.2007.00736.x.

Leitão S. (2010) An overview of current and future agenda of Brazilian policy in science, technology and innovation, Brasília: Ministry of Science, Technology and Innovation. Available at: https://www.rvo.nl/sites/default/ files/2014/06/Leitao_Brazil_0.pdf, accessed 11.03.2018.

Murray G.C., Marriott R. (1998) Why has the investment performance of technology-specialist, European venture capital funds been so poor? Research Policy, vol. 27, pp. 947-976.

OECD (1996) Venture Capital and Innovation, Paris: OECD. Available at: http://www.oecd.org/ dataoecd/35/59/2102064.pdf, accessed 12.11.2017.

OECD (1997a) National Innovation Systems, Paris: OECD. Available at: http://www.oecd.org/dataoecd/35/56/2101733. pdf, accessed 26.02.2016.

OECD (1997b) Government Venture Capital for Technology-based Firms, Paris: OECD. Available at: http://www. oecd.org/dataoecd/14/7/2093654.pdf, accessed 12.11.2017.

OECD (1999) Managing National Innovation Systems, Paris: OECD. Available at: http://echo.iat.sfu.ca/library/ oecd99_managing_National_IS.pdf, accessed 12.11.2017.

OECD (2014) Strategic Public/Private Partnerships in Science, Technology and Innovation, Paris: OECD.

Rothwell R. (1994) Towards the Fifth-generation Innovation Process. International Marketing Review, vol. 11, no 1, pp. 7-31. Available at: https://doi.org/10.1108/02651339410057491, accessed 26.02.2016.

UN (2009) United Nations Framework Convention on Climate Change (UNFCCC). Recommendations on future financing options for enhancing the development, deployment, diffusion and transfer of technology under the Convention, Vienna: United Nations. Available at: http://unfccc.int/resource/docs/2009/sb/eng/02.pdf, accessed 12.11.2017.

UNIDO (1996) Guidelines on Infrastructure Development through BOT Projects (BOT Guidelines UNIDO.95.6.E), Vienna: UNIDO.

World Bank (2017) Project Preparation Facility: Increase in Commitment Authority and Enhanced Scope (Chair Summary), Washington, D.C.: World Bank Group. 